\title{
Reflection on the Social Security System Reform for College Teachers \\ Shufeng $\mathrm{Ni}$ \\ Jilin Agricultural University \\ 512375850@qq.com
}

Keywords: Common colleges; Teachers; Social security system; System reform

\begin{abstract}
At present, the social security system of China is being reformed and improved while the reform for college teachers has been highlighted. This paper summarizes the social security reform for college teachers and also analyzes its current condition, explores into the necessity to perfect it and studies on the measures to carry out better reform.
\end{abstract}

\section{Introduction}

The social security system reform for college teachers is an inevitable demand of times, which will play a rood role in social security system reform and improve the higher education level. Therefore, we have to keep a reasonable social security system for common college teachers, which asks us to continually carry out reform based on the current development situation, Thus, faculties can do better work, which will facilitate the development of common colleges in China.

\section{Summary on the Social Security System Reform for Common College Teachers}

The reform for college teachers' social security system can be divided into two stages, which is from the foundation of new China to the beginning of 1980s and 1980s until now.

From the foundation of new China to 1980 s, the social security system of college teachers experienced two period of country-society-personal guarantee and country-state owned units guarantee. During these periods, the social security system for college teachers is not independent, which truly changed in terms of contents, performance and main body though. To begin with, government and units undertake the work set restrictions while college undertake relative responsibilities based on this. They can enjoy social security treatment without paying anything; secondly, it is comprehensive guarantee. That is to say, teachers can enjoy certain guarantee service in position even when getting retired and sick. Finally, it should be closed operation. It has relatively low efficiency and various departments in colleges lack communication, thus the payment and work ratio is uneven.

From 1980s until now the socialization of social security, as the opposite of government and unit monody has been gradually paid attention to while a glittering array of policies has been implemented with great achievement. From the opening up and reform until now, traditional planned economy has been changed into market economy, that is to say the economic and social based has been changed while the social security system follows. Affected by market economy, teachers can still get compensations from the social security system after retired while they have to participate in social pooling to get compensations for medical treatment and after losing a job. Colleges, as an important part to output talents, the social security system for college teachers actually trigger indirect effect. By reforming the social security system for college teachers, common college will get better development.

\section{Current Situation of Social Security System for College Teachers}

Social security is the product of industrial reform and socialization, which plays in a big role in social civilization and is the focus in academicals and industrial field. Along with the development of knowledge economy, deepened reform of educational system as well as continuous perfection of market economy, the social status and salary of teachers have been improved. However, there are still shortages in terms of social security for them and the income as well as distribution system will 
be the first to bear the brunt, which will actually hinder the health and stable development go higher education in China.

Firstly, the social security system for college teachers is not regulated and legalized. Even though there are laws for it, they are generalized and will affect the nature and function of social security as well as the distribution method.

Secondly, the social security system is not in accordance with the salary distribution. The salary system for teachers has been reformed continually, and their income and working environment have both been improved a lot. However, the social security system has not been changed, leading to the fact that retired teachers have to pay a lot on living and medical care, impeding the deepens reform and development of education system.

Finally, the social security system for teachers is poor and relative work is decentralized rather than unified, which will lead to the chaos of its management and affect its normal operation, and further hinder the deeper reform of income distribution system.

\section{Necessity to Perfect the Social Security System for College Students}

Help to Construct a Unified, Multi-level and All-round Social Security System. The social security system in China should be adapted to the socialist market economy with capitals from various channels, various guarantee methods and socialized management as well as service etc. China has continually carried out reform and exploration on social security system and made great contribution to it. However, there are still problems in terms of coverage range and implementation.

In fact, lots of colleges are run by the state and supported by state funding which will inevitably bring limited for the social security system reform for teachers. As a result, it cannot be highly socialized and various social security systems are still adopting normalized pattern. Overall, there are differences among social security systems for teachers, which hinder its construction and perfection. Concerning this, China should take relative measures to facilitate its reform to perfect it and make relevant contributions.

Help to Control Proper Talent Flow and Optimize Human Resources. To operate the economical mode based on fundamental role market mechanism and resource allocation played to create a market economy mode is beneficial to enhance the flow of productive elements throughout the whole society so as to realize optimal resource setting. The social security system for college teachers plays a big part in human resource optimization and proper flow of talents. At present, the social security system is the product of socialized mass production. Even though it won't directly produce during the economic process, its emergence and development cannot be separated from the economic process.

After the formation and shaping of social security system, it will act as a variable during the economic process. As an important part of productive elements, human resources play a big role in the market because the competition among talents can help to realize the competition of the market. College teachers belong to human resources and are able to cultivate lots of talents, they play a bigger and bigger role nowadays in undertaking social responsibility, so teachers are colleges compete for. The higher education in China is going through deep reform and total retainer system will be fully operated. As a result, colleges will get more frequent connections with state-owned offices because colleges have to output many talent resources, thus there will be a big flow in terms of teachers. A lot of college teachers implement social security system close to the state-owned office, which to some extent, can even out the differences and become beneficial for talents flow. Finally, it can realize optimal human resource setting and further perfect socialist market economy.

Help to Facilitate the All-round Development of Teachers. The speed of economic growth and improvement of productive force are considered as important measures to evaluate the development condition of modernization. Except for economic structure, social environment and political operation, we should also study on the development level of talents. The fact is that the development of talents cannot be separated from the society and only a sound social security system can help to make better development for human beings. College teachers are important creator and carriers for creating culture and knowledge, and they are also parts of citizens. Teachers are conducive too the 
advancement of society and development of civilization and are granted with certain special rights by the state and society, among which social security system is a part.

In hierarchy of needs, there are needs in terms of physiology, safety, social networking, respect and self-realization from which we can see that if people are satisfied in terms of physiology and safety, there will be follow up like social networking, respect and self-realization. So, we have to strengthen the social security for college teachers so as help them be focused while working and learning, which is also helpful to realize their value.

Help to Realize Three Main Tasks of Colleges. Innovation, dissemination and application of knowledge is the basic function of modern colleges while scientific research, training and social services are three major tasks. The economic and social attributes of colleges are determined based on the function. In terms of economics, quasi-public goods are main products and service, colleges are mainly engaged in scientific research, talents cultivation and social service, which means that colleges are non-profit organizations with high efficiency. This economic property means that market and government are main sponsors of money while government fund is the main source and market channel means service charge and social donation. That is to say, if the government cannot provide guarantee for teachers, it will be difficult for them to have enough savings to face the risk brought by the market.

Knowledge is the core value of modern colleges. Knowledge creation, dissemination and application help colleges to cultivate high-intellectual talents team and become a knowledge organization with talents as the core. Concerning this, teachers' initiative, enthusiasm and creation have a big effect on this property. So, in order to guarantee high-intellectual talents cultivation, we should respect the requirement of teachers to reform and perfect their social security system, keep the stability of teacher team to better facilitate the human capital and human resource allocation. By taking the initiative of teachers, they are able to create better conditions for the salary distribution system.

\section{Effective Measures for Social Security System of College Teachers}

Unify Thoughts Deepen Understanding. Only by guaranteeing the correctness of thoughts can we guarantee the correctness and efficiency of the results. The social security system for college teachers lost touch with the high-efficiency distribution system, which is related to people's thoughts and education level. Not only the designers for their social security system lags behind but also teachers' thoughts. While facing injury, aging, retirement and natural disasters, they need basic living conditions to maintain the production, and thus people will think of national guarantee. However, in the premise of understanding the connection between college education and social security in market economic conditions, they are unable to fully realize the critical role the social security system plays for the development of colleges.

College teachers, as the weakest force in the process of reforming and developing social security system should be paid attention to. Colleges should make good pension reform in the premise of making good pension security system.

Understand the Problem and Clear Responsibilities. The construction of social security system for college teachers should be built based on the reality of colleges, which should be affordable according to the real running and financial condition in case it cannot be implemented. While making the social security system, colleges can refer to the examples of foreign colleges, but they cannot totally copy.

In terms of responsibilities, we should clear the relation between historical responsibility and realistic responsibility; the relation among government, market, college and the society; the relation between central government and provincial government. Colleges should facilitate the construction for teachers' social security system and trying unremitting efforts to find out the security system which can adapt to their own features so as to guarantee the reliability and effectiveness.

Innovate the System and Perfect the Mechanism. To begin with, we should perfect the distribution system and add deferred distribution system based on the current one. Current distribution can be regarded as the payment and bonus for teacher's work to satisfy their basic needs while deferred distribution is adopted to encourage teachers with social security and welfares, which can be 
deemed as important measures to keep talents. What's more, the education department should allow colleges to build relative security policies related to the social security system such as supplementary pension insurance, medical insurance and housing fund. In addition, welfare system should be set based on the real condition of colleges so that teachers can enjoy academic vacation and reeducation. Finally, the government should play a role of market regulation so as to lead the transfer of social resources to public welfare based on developing endowment insurance and medical insurance, regulating fiscal and tax policy.

\section{Conclusion}

The reform of social security system for college teachers has a long way to go. While facing such a complicated task, colleges should design proper goals for social security system reform based on real condition. Based on that colleges can fully understand the problems and dilemma, guarantee the effectiveness, provide favorable working environment and facilitate the development of universities.

\section{References}

[1] Wen Yueran, Ouyang Jie. Study on the occupation characteristics and distribution reform of college teacher [J] . China Higher Education Research, 2004. Supplementary issue:11·19

[2] Gao shushing. The social security system reform in China : review and reflection [J] . Economics Information,2005,(2)

[3] Lou Shizhou. Discuss on the social security reform for teachers ,2005,(2) Education Science, 2000,(3).

[4] Yuandong, Sun Dianming. Deepen the salary distribution reform to advance the social security system-based on the Life Cycle Theory [J] . Study on the teachers' quality of Chinese colleges 2007, (04).

[5] Liu Jianjun. Study on the right and security mechanism of college students [J] . Career Horizon, 2011, (04).

[6] Huang Yihong. Discuss on guarantee of teacher's right [J] Modern reading tion) ,2011,(01)

[7] Xue Meiqing. Investigation and measure research on the social security for college teachersTake J College as an example Journal of Jiangsu Teachers University of Technology, 2011, (07). 